\title{
THE EFFECTS OF PATIENT POSITION ON EARLY COMPLICATIONS OF SPINAL ANESTHESIA INDUCTION IN ARTHROSCOPIC KNEE SURGERY
}

\author{
Esra Kongur ${ }^{1}$, Sedat Saylan ${ }^{2}$ and Ahmet Eroğlu ${ }^{2}$ \\ ${ }^{1}$ Department of Anesthesiology and Resuscitation, Kanuni Education and Research Hospital, Trabzon, Turkey; \\ ${ }^{2}$ Karadeniz Technical University Faculty of Medicine, Department of Anesthesiology and Intensive Care Medicine, \\ Trabzon, Turkey
}

\begin{abstract}
SUMMARY - Spinal anesthesia is widely used in different patient positions to create efficient and rapid anesthesia induction in surgical interventions. Early and late complications of spinal anesthesia may vary according to the type of needle, drug dose and concentration, patient weight and height, puncture technique, and position of the patient. This study aimed to prospectively compare early complications of spinal anesthesia between patients in sitting and lateral decubitus positions with motor block onset time and sensory block time to T10 level. Spinal anesthesia was performed in 100 ASA I-II patients aged 18-65 years (group $\mathrm{S}=48$; and group L=52) undergoing arthroscopic knee surgery. Hemodynamic data, early complications, sensory and motor block onset times were recorded. Systolic, diastolic and mean arterial pressures were significantly lower in lateral decubitus position as compared to sitting position after spinal anesthesia induction. Arterial blood pressure values decreased significantly in lateral decubitus position as compared with sitting position. Motor block onset time and sensory block onset time were shorter in lateral decubitus position than in sitting position. Accordingly, sitting position could be suggested during induction of spinal anesthesia because it was associated with less pronounced decrease in blood pressures.
\end{abstract}

Key words: Spinal anesthesia; Induction patient position; Lateral decubitus position; Sitting position; Early complications

\section{Introduction}

Spinal anesthesia is a simple method that is commonly used for surgical interventions to create efficient and rapid anesthesia induction. Early and late complications of spinal anesthesia may vary in patients undergoing operation with spinal anesthesia, depending on particular factors such as the type of needle, drug dose and concentration, patient weight and height, puncture technique, and position of the patient. The most common early complications include

Correspondence to: Sedat Saylan, MD, Karadeniz Technical University Faculty of Medicine, Department of Anesthesiology and Intensive Care Medicine, Trabzon, Turkey

E-mail: sedatsaylan@yahoo.com

Received June 8, 2020, accepted September 29, 2020 bradycardia and hypotension, while headache is a common late complication. Spinal anesthesia is widely used especially for operations of pelvis, perineum and lower limb ${ }^{1-5}$.

Spinal anesthesia can be induced in lateral decubitus, sitting or prone positions. Decubitus and sitting positions are most commonly used. Since patients are switched to supine position immediately after anesthesia is induced in sitting position, the risk of postural hypotension is remarkably high ${ }^{1-3}$. Long-standing and severe hypotension is observed when spinal anesthesia is induced in sitting position in healthy patients undergoing cesarean section under combined spinal-epidural anesthesia ${ }^{6}$. However, a study conducted in elderly patients compared spinal anesthesia that was induced in sitting and lateral decubitus positions, 


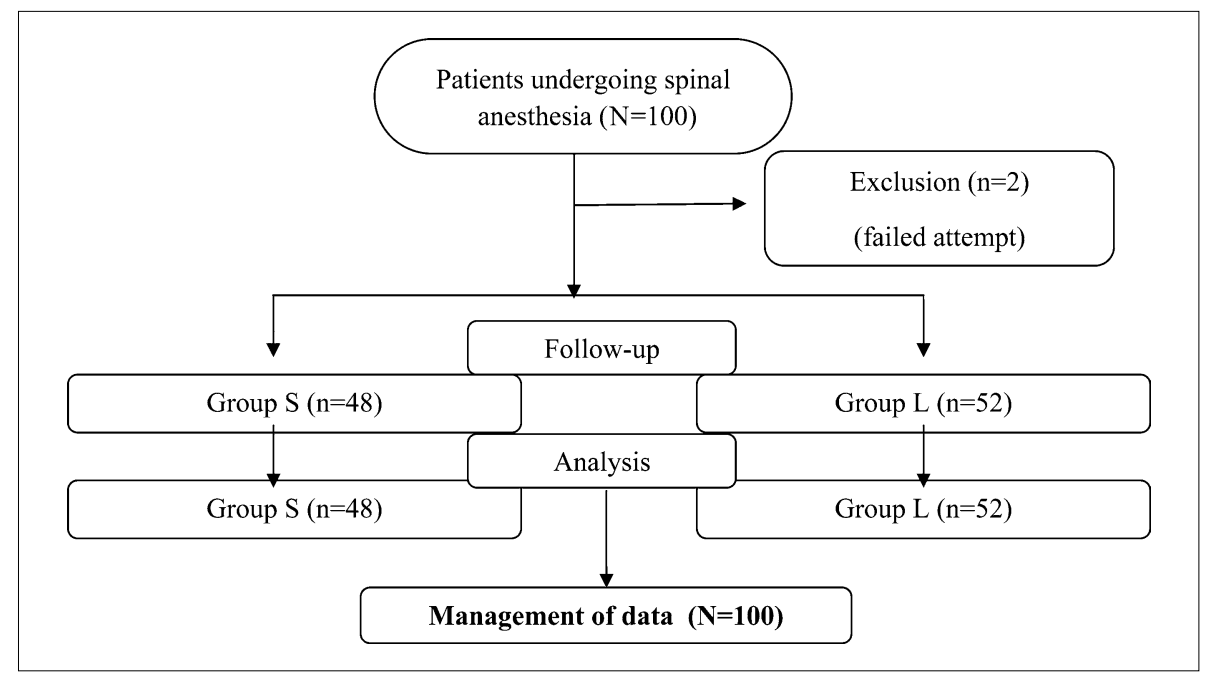

Fig. 1. Flowchart of the study.

Group $\mathrm{S}=$ sitting position; group $\mathrm{L}=$ lateral decubitus position

and reported early onset of anesthesia in sitting position, although there was no significant difference according to hemodynamic parameters and onset of motor block ${ }^{7}$.

This study was conducted to investigate whether patient position during induction of spinal anesthesia had an impact on hypotension and other early complications, and it was planned to compare the most preferred two positions, namely, lateral decubitus and sitting positions. The outcomes of this study are expected to potentially influence the choice of patient position in spinal anesthesia. This study aimed to prospectively compare early complications of spinal anesthesia, onset of motor block and mean time to achieve T10 level block in patients undergoing operation under spinal anesthesia in sitting and lateral decubitus positions.

\section{Patients and Methods}

The study was performed in patients aged 18-65 with American Society of Anesthesiologists (ASA) I-II physical status, scheduled for elective arthroscopic knee surgery and eligible for spinal anesthesia. It was planned to recruit patients planned to undergo elective arthroscopic knee surgery that were eligible for spinal anesthesia, age range 18-65 years, had no contraindication for spinal anesthesia, and had ASA I or II status. Upon deciding on spinal anesthesia induction in sitting or lateral position, patients were divided into two groups, group S (anesthesia induction in sitting position) and group $\mathrm{L}$ (anesthesia induction in lateral decubitus position). The study was prospectively conducted by comparing pre-anesthesia and intraoperative hemodynamic data in patients in the two groups having undergone arthroscopic knee surgery in the orthopedics operating room. All preoperative routine tests and study reports were reviewed and all patients were informed about the procedure and their consents were obtained. Patients were not allowed to eat solid foods 6 hours before surgery and liquid foods 4 hours before surgery. Patients other than ASA I-II and patients with other comorbidities that would impair their hemodynamics were not included in the study, as this may affect the outcome of the study. Patients under age 18 and over 65, those with contraindications for spinal anesthesia, patients allergic to local anesthetics, patients who did not accept spinal anesthesia, and pregnant women were not included in the study. In addition, patients who could not receive spinal anesthesia or whose spinal anesthesia level was not sufficient for surgical procedure were excluded from the study (Fig. 1).

Patients were intravenously infused crystalloid fluid $(0.9 \% \mathrm{NaCl})$ at a dose of $10 \mathrm{mg} / \mathrm{kg}$ for 30 minutes before being positioned on the operating table. Systolic arterial pressure (SAP), diastolic arterial pressure (DAP) and mean arterial pressure (MAP) were preand intra-operatively measured with noninvasive arte- 
rial pressure monitor, while apical heart beats and heart rhythm were monitored with an electrocardiography (ECG) device, peripheral oxygen saturation ( $\mathrm{SpO} 2)$ was measured with pulse oximetry, and body temperature was measured with a thermometer. The presence of shivering, nausea, vomiting, respiratory failure, allergic reaction and total spinal block was determined according to observations and patient reports. All these data were recorded before spinal anesthesia and at 1 minute, 5 minutes, 10 minutes, 15 minutes, 30 minutes and 60 minutes after spinal anesthesia.

Spinal anesthesia was induced in sitting position in 48 patients (group $\mathrm{S}$ ) and in lateral decubitus position in 52 patients (group L). The groups were formed randomly (picking a color-coded paper in a closed envelope). After asepsis and antisepsis conditions were met, a 22-gauge Quincke spinal needle was inserted into the subarachnoid space with median approach at the intervertebral disc level L2-3 or L3-4. After free cerebrospinal fluid (CSF) flow was observed in each patient, 3-3.5 mL 0.5\% hyperbaric bupivacaine was administered at a dose of $15-17.5 \mathrm{mg}$ over 10 seconds, without barbotage, into the subarachnoid space.

After local anesthetic agent was administered, $\mathrm{pa}^{-}$ tients were immediately switched to supine position.

Sensory block level of spinal anesthesia was determined with pin prick test. T10 level was deemed as sufficient sensory block level for operation. Sensory block level was checked at 30-second intervals after intrathecal injection and mean time to T10 level was recorded.

Bromage motor block scale was used to determine the level of motor block. Bromage 2-3 was accepted as the motor block level and onset of motor block sufficient for operation, and onset of motor block was recorded by evaluating motor block level every $30 \mathrm{sec}-$ onds. Lumbar intervertebral disc level used for intrathecal injection, number of lumbar puncture attempts and dermatome of sensory block level, as well as the mean duration of intrathecal injection (seconds) were recorded.

Hypotension was defined as a decline in systolic arterial pressure by $25 \%$ relative to arterial blood pressure before intrathecal injection or systolic arterial pressure $<90 \mathrm{~mm} \mathrm{Hg}$. Bradycardia was defined as a decline in heart rate by $25 \%$ relative to heart rate before intrathecal injection or heart rate $<50$ beats $/ \mathrm{min}$. Respiratory rate $<6 / \mathrm{min}$ or $\mathrm{SpO} 2<85 \%$ was regarded as respiratory depression. Infusion of crystalloid fluid was intraoperatively maintained at a rate of $6-8 \mathrm{~mL} / \mathrm{kg} / \mathrm{h}$. All treatment methods to manage possible complications were available (intravenous (IV) colloid and crystalloid fluid support and IV ephedrine $10 \mathrm{mg}$ for hypotension and IV atropine $0.5 \mathrm{mg}$ for bradycardia). Medical treatments started to manage complications and total volume of intravenous fluid support was recorded.

\section{Statistical analysis}

The SPSS for Windows 13.0 software package was used for descriptive statistics, frequency tables, and intra- and inter-group differences. The $\chi^{2}$-test was used in inter-group analysis of qualitative data. MannWhitney $U$ test was used for numeric parameters without normal distribution and Student's t-test was used for numeric parameters with normal distribution. The level of statistical significance was set at $\mathrm{p}<0.05$. Power analysis was performed for two groups in the sample size study. When the effect size was considered as Cohen $\mathrm{d}=0.6,80 \%$ power would be obtained by including 90 patients in the study $(\alpha=0.05)$ (G. Power version 3.9.1.2, Germany). The study was completed with 100 patients (group $\mathrm{S}=48$ and group $\mathrm{L}=52$ ).

\section{Results}

Spinal anesthesia was induced in sitting position in 48 patients (group $\mathrm{S}$ ) and in lateral decubitus position in 52 patients (group L) scheduled for arthroscopic knee surgery. In two group $\mathrm{S}$ patients, the procedure was switched to general anesthesia, i.e. due to inability to induce spinal anesthesia and inadequate spinal block level in one patient each. These two patients were excluded from the study.

There were no statistically significant betweengroup differences according to heart rate, peripheral oxygen saturation, body temperature, duration of lumbar puncture, number of lumbar puncture attempts, volume of fluid infused, intervertebral disc level used for lumbar puncture, level of sensory block, and the need for atropine, adrenaline and ephedrine ( $p>0.05)$.

Demographic characteristics, duration of surgery, and ASA percentages of the cases are shown in Table 1 . There was no statistically significant difference between the groups $(p>0.05)$. There was no statistically 
Table 1. Demographic characteristics of patients and duration of surgery

\begin{tabular}{|l|l|l|}
\hline & Group S $(\mathrm{n}=48)$ & Group L $(\mathrm{n}=52)$ \\
\hline Female/Male & $14 / 34$ & $17 / 35$ \\
\hline Age (years) & $41.67 \pm 13.86$ & $38.88 \pm 13.72$ \\
\hline Height $(\mathrm{cm})$ & $174.08 \pm 8.34$ & $170.65 \pm 8.71$ \\
\hline Weight $(\mathrm{kg})$ & $80.38 \pm 13.68$ & $79.27 \pm 12.60$ \\
\hline $\begin{array}{l}\text { Duration of } \\
\text { operation (minutes) }\end{array}$ & $70.94 \pm 27.51$ & $75.38 \pm 25.00$ \\
\hline ASA I-II & $31 / 17$ & $32 / 20$ \\
\hline
\end{tabular}

Group $\mathrm{S}=$ sitting position; group $\mathrm{L}=$ lateral decubitus position; ASA = American Society of Anesthesiologists

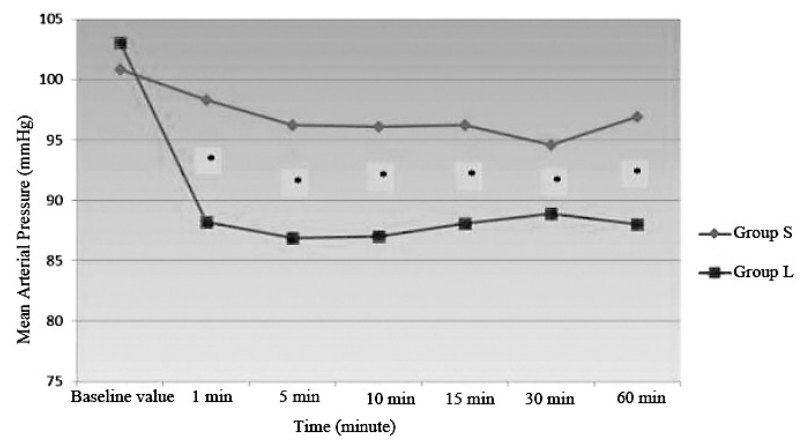

Fig. 2. Mean arterial pressure values in group $S$ and group $L$ patients.

Group $\mathrm{S}$ = sitting position; group $\mathrm{L}$ = lateral decubitus position

significant between-group difference according to heart rate either $(p>0.05)$.

The values of SAP at 1, 5, 10, 15 and 60 minutes were statistically significantly lower in group $\mathrm{L}$ than in group $S(p<0.05)$. There was no statistically significant difference between the groups in SAP values before spinal anesthesia and at $30^{\text {th }}$ minute $(p>0.05)$.

The values of DAP at 1, 5, 10, 15 and 60 minutes were statistically significantly lower in group $L$ than in group $S(p<0.05)$. There was no statistically significant difference between the groups in DAP values before spinal anesthesia and at $30^{\text {th }}$ minute $(p>0.05)$.

The values of MAP at 1, 5, 10, 15 and 60 minutes were statistically significantly lower in group $L$ than in group $S(p<0.05)$. There was no statistically significant difference between the groups in MAP values before spinal anesthesia ( $p>0.05$ ) (Fig. 2).

The time for group $\mathrm{S}$ to get into T10 dermatome was statistically significantly longer as compared with group L ( $\mathrm{p}=0.000)$. Motor block onset time was statis-
Table 2. Time to sensory block at T10 dermatome level and time to onset of motor block

\begin{tabular}{|l|l|l|l|}
\hline & $\begin{array}{l}\text { Group S } \\
(\mathrm{n}=48)\end{array}$ & $\begin{array}{l}\text { Group L } \\
(\mathrm{n}=52)\end{array}$ & $\mathrm{p}$-value \\
\hline $\begin{array}{l}\text { Time to sensory } \\
\text { block at level of T10 } \\
\text { dermatome (min) }\end{array}$ & $3.34^{*} \pm 1.14$ & $2.49 \pm 0.48$ & $\mathbf{0 . 0 0 0}$ \\
\hline $\begin{array}{l}\text { Time to onset of } \\
\text { motor block (min) }\end{array}$ & $2.99^{*} \pm 0.77$ & $2.75 \pm 0.61$ & $\mathbf{0 . 0 0 0}$ \\
\hline
\end{tabular}

Group $\mathrm{S}$ = sitting position; group $\mathrm{L}=$ lateral decubitus position; *statistically significant

Table 3. Side effects

\begin{tabular}{|l|l|l|l|}
\hline & $\begin{array}{l}\text { Group S } \\
(\mathrm{n}=48, \%)\end{array}$ & $\begin{array}{l}\text { Group L } \\
(\mathrm{n}=52, \%)\end{array}$ & $\mathrm{p}$-value \\
\hline Hypotension & $9(18.8 \%)$ & $20(38.5 \%)$ & 0.051 \\
Bradycardia & $17(35.4 \%)$ & $17(32.7 \%)$ & 0.834 \\
Shivering & $2(4.2 \%)$ & $3(5.8 \%)$ & 0.712 \\
Nausea-vomiting & $1(.1 \%)$ & $1(1.9 \%)$ & 0.954 \\
Respiratory failure & $0(0 \%)$ & $0(0 \%)$ & 1 \\
Allergic reaction & $0(0 \%)$ & $1(1.9 \%)$ & 0.251 \\
Total spinal block & $0(0 \%)$ & $0(0 \%)$ & 1 \\
\hline
\end{tabular}

Group $\mathrm{S}$ = sitting position; group $\mathrm{L}=$ lateral decubitus position

tically significantly longer in group $\mathrm{S}$ than in group $\mathrm{L}$ $(\mathrm{p}=0.000)$ (Table 2).

There was no between-group statistically significant difference according to side effects $(p>0.05)$ (Table 3).

\section{Discussion}

The level of sensory and motor blocks, which are induced by injecting local anesthetic agent into the CSF, is influenced by many factors such as age, height, concentration and dose of local anesthetic agent, patient position, direction of needle, and repeated drug injection. High level of sensory block is one of the most common reasons of hypotension that develops after spinal anesthesia ${ }^{1-3}$. In this study, hypotension and bradycardia were observed in 9 and 17 group $\mathrm{S}$ $(\mathrm{n}=48)$ patients, and in 20 and 17 group $\mathrm{L}(\mathrm{n}=52) \mathrm{pa}-$ tients, respectively, yielding no statistically significant between-group difference according to development of bradycardia and hypotension. Overall, bradycardia 
was observed in $34 \%$ and hypotension in $29 \%$ of patients operated under spinal anesthesia.

Kelly et al. emphasized the importance of hypotension in hemodynamic variables during spinal anesthesia in two different positions. Lateral positioning for spinal anesthesia requires lower total doses of vasoconstrictors for blood pressure maintenance while delaying the onset of hypotension ${ }^{1}$. Šklebar et al. report on the importance of using crystalloids, colloids, vasopressors, ephedrine and phenylephrine in the treatment of spinal anesthesia-induced hypotension ${ }^{8}$. In our study, bradycardia was the most common complication, immediately followed by hypotension. We used ephedrine as a vasopressor in addition to fluid support in the treatment of hypotension.

Studies comparing spinal anesthesia induced by hyperbaric bupivacaine in sitting and lateral decubitus positions report that hypotension was less common in sitting position ${ }^{9,10}$. In this study, alterations in SAP, DAP, and MAP values at 1, 5, 10, 15 and 60 minutes after spinal injection were significantly lower in the lateral decubitus group relative to the sitting group. Our study demonstrated that lower volume of anesthetic agent flowed in cephalic direction in sitting position relative to lateral decubitus position even if the patient was placed in supine position immediately after subarachnoid injection. A study conducted on cesarean section cases using hyperbaric bupivacaine 6.6 $\mathrm{mg}$ found that less anesthetic agent flowed in cephalic direction in sitting position relative to lateral decubitus position ${ }^{9}$. Another study reports that the lower baricity of local anesthetic agents is used for spinal anesthesia induction in sitting position, the higher is the sensory block level ${ }^{11}$.

Kim et al. ${ }^{12}$ compared features of sensory block and hemodynamic changes in patients aged $\geq 65$ years, who were switched to supine position immediately after spinal anesthesia had been induced in lateral position and those switched to supine position two minutes after spinal anesthesia had been induced in sitting position. The authors used low-dose hyperbaric bupivacaine (6.5 $\mathrm{mg}$ ) and found that although there was no betweengroup difference regarding alterations in the mean arterial blood pressure, three patients required atropine or ephedrine in lateral decubitus position, whereas none of the patients required ephedrine in sitting position. In conclusion, hypotension was observed in fewer patients from the sitting group. Since by far higher doses of lo- cal anesthetic agent (15-17.5 mg) were used in this study in comparison with the study conducted by Kim et al. ${ }^{12}$, significantly lower values might have been obtained in systolic arterial blood pressure, diastolic arterial blood pressure and mean arterial blood pressure values in the lateral decubitus group.

Fredman et al. ${ }^{13}$ used hyperbaric bupivacaine at a dose of $10 \mathrm{mg}$ in 90 elderly patients (aged $>65$ years) and compared the effect of spinal anesthesia on perioperative hemodynamic stability and patient comfort in two groups (sitting and lateral decubitus positions). There was no significant between-group difference regarding alteration in the mean arterial blood pressure. In our study, systolic arterial blood pressure, diastolic arterial blood pressure and mean arterial blood pressure values were significantly lower in the lateral decubitus position group. In our study, patients underwent surgery in supine position, whereas in the study by Fredman et al. ${ }^{13}$ transurethral surgery was carried out in lithotomy position. Lithotomy position causes postural drainage from lower limb to central body, and venous return is corrected by reducing volume deficit that results from spinal anesthesia ${ }^{13}$. This fact and administration of a lower dose of local anesthetic agent can explain why the mean arterial blood pressure outcomes in the study conducted by Fredman et al. ${ }^{13}$ do not support our results on the mean arterial blood pressure.

Shahzad and Afshan ${ }^{7}$ compared the effect of spinal anesthesia induction in lateral decubitus and sitting positions on sensory and motor blocks and hemodynamic parameters in 70 patients aged $\geq 60$ years. In contrast to our study, no statistically significant difference was found between the two groups regarding alterations in systolic arterial blood pressure, diastolic arterial blood pressure and mean arterial blood pressure in that study. Outcomes of that study might not support the results of our study, since both low-dose and isobaric bupivacaine was used and cephalic spread was not largely observed, similar to the lateral decubitus group in our study. Han et al. report on the results similar to ours in their study on geriatric patients (aged 65-85 years). The authors emphasize that combined spinal epidural anesthesia performed in sitting position is safer and more effective in elderly patients undergoing elective total hip replacement ${ }^{14}$.

Obasuyi et al. induced spinal anesthesia in sitting and lateral decubitus positions in cesarean section cas- 
es in order to compare the effect on hemodynamic parameters, but found no significant between-group difference in the lowest systolic arterial blood pressure values. However, in contrast to our study, the mean arterial blood pressure values were significantly lower in the sitting group relative to the lateral decubitus group. In the same study, the incidence of hypotension was significantly lower in the lateral group ${ }^{15}$. Accordingly, the results of their study varied from those recorded in our study.

Another significant outcome of our study was time to the onset of sensory block at the level of T10 dermatome, which was determined as the time of sensory block onset in our study. This time was 3.34 minutes in sitting group and 2.49 minutes in lateral decubitus group, yielding a statistically significant betweengroup difference $(p<0.05)$. A similar result has been reported from a study that used hyperbaric bupivacaine in cesarean section cases ${ }^{16}$. In that study, time to the onset of sensory block was 115 seconds and 240 seconds in the lateral group and sitting group, respectively. Another study ${ }^{15}$ using isobaric bupivacaine reports that time to the onset of sensory block at the level of T6 dermatome was significantly shorter in sitting group (3.4 $\mathrm{min}$ ) as compared with lateral decubitus group $(5.1 \mathrm{~min})$. Both shorter time and a reverse outcome were observed in our study, since both highdose and hyperbaric local anesthetic agent were used.

Another outcome of our study was the significantly shorter time to the onset of motor block in lateral decubitus position in comparison with sitting group. Kim et al. ${ }^{12}$ reviewed motor block scores at 5, 10, 15 and 20 minutes and report that higher scores were noted in lateral decubitus position at all time points, albeit not statistically significant. In another study ${ }^{14}$, where isobaric bupivacaine was used in cesarean section cases, Bromage motor block score was addressed rather than time to the onset of motor block. Another isobaric bupivacaine study ${ }^{7}$ measured Bromage motor block score at predetermined intervals. Neither study could find significant between-group differences. The contradictory results of our study and outcomes of those studies probably were due to the use of isobaric bupivacaine and Bromage motor block score measurement at the end of operation in the first study.

Our study may have some limitations. Our patients were selected from the ASA I-II risk group, whereas patients from the ASA III risk group with high co- morbidity were not included in the study. Major lower extremity surgeries with higher hemodynamic variables, trauma patients, and lower limb manipulations in which blood loss was expected were not included in the study. In addition, maximum level of sensory dermatome was not compared between the groups.

Finally, most of the previous studies addressing this issue recruited elderly patients or cesarean section cases. Our study included patients aged 18 to 65 years, not pregnant, and with ASA score I-II. Study results can help making final decision by eliminating other factors that may influence hemodynamic parameters.

In conclusion, our study demonstrated that induction of spinal anesthesia led to a statistically significant decrease in arterial blood pressure in the lateral decubitus group in comparison with the sitting group. Moreover, it was also demonstrated that time to the onset of motor and sensory blocks was significantly shorter in the lateral group. Our study showed the induction of spinal anesthesia in patients with unstable hemodynamic parameters to be safer in sitting position relative to lateral decubitus position.

\section{References}

1. Kelly JD, McCoy D, Rosenbaum SH, Brull SJ. Haemodynamic changes induced by hyperbaric bupivacaine during lateral decubitus or supine spinal anaesthesia. Eur J Anaesthesiol. 2005;22(9):717-22, http://dx.doi.org/10.1017/s026502150500 1183

2. Spielman FJ, Watson CB. Spinal anesthesia. JAMA. 1983;249: 734-6, http://dx.doi.org/10.1001/jama.1983.03330300026027

3. Wildsmith JAW, Rocco AG. Current concepts in spinal anesthesia. Reg Anesth. 1983;10:119-24.

4. Erturk E, Tutuncu C, Eroglu A, Gokben M. Clinical comparison of $12 \mathrm{mg}$ ropivacaine and $8 \mathrm{mg}$ bupivacaine, both with 20 microg fentanyl, in spinal anaesthesia for major orthopaedic surgery in geriatric patients. Med Princ Pract. 2010;19(2): 142-7, http://dx.doi.org/10.1159/000249581

5. Eroglu A, Saracoglu S, Erturk E, Kosucu M, Kerimoglu S. A comparison of intraarticular morphine and bupivacaine for pain control and outpatient status after an arthroscopic knee surgery under a low dose of spinal anaesthesia. Knee Surg Sports Traumatol Arthrosc. 2010;18(11):1487-95, http://dx. doi.org/10.1007/s00167-010-1061-0

6. Yun EM, Marx GF, Santos AC. The effects of maternal position during induction of combined spinal-epidural anesthesia for cesarean delivery. Anesth Analg. 1998;87:614-8, http://dx. doi.org/10.1097/00000539-199809000-00023

7. Shahzad K, Afshan G. Induction position for spinal anaesthesia: sitting versus lateral position. J Pak Med Assoc. 2013;63 (1):11-5. PMID: 23865124 
8. Šklebar I, Bujas T, Habek D. Spinal anaesthesia-induced hypotension in obstetrics: prevention and therapy. Acta Clin Croat. 2019;58(Suppl 1):90-5, http://dx.doi.org/10.20471/acc.2019. $58 . s 1.13$

9. Coppejans HC, Hendrickx E, Goossens J, Vercauteren MP. The sitting versus right lateral position during combined spinal-epidural anesthesia for cesarean delivery: block characteristics and severity of hypotension. Anesth Analg. 2006;102(1):243-7, http: //dx.doi.org/10.1213/01.ane.0000189049.11005.26

10. Patel M, Samsoon G, Swami A, Morgan B. Posture and the spread of hyperbaric bupivacaine in parturients using combined spinal epidural technique. Can J Anaesth. 1993;40: 943-6, http://dx.doi.org/10.1007/BF03010097

11. Hallworth SP, Fernando R, Columb MO, Stocks GM. The effect of posture and baricity on the spread of intrathecal bupivacaine for elective cesarean delivery. Anesth Analg. 2005; 100:1159-65, http://dx.doi.org/10.1213/01.ANE.00001495 48.88029.A2

12. Kim HY, Lee MJ, Kim MN, Kim JS, Lee WS, Lee KC. Effect of position changes after spinal anesthesia with low-dose bupivacaine in elderly patients: sensory block characteristics and hemodynamic changes. Korean J Anesthesiol. 2013;64(3):2349, http://dx.doi.org/ 10.4097/kjae.2013.64.3.234

13. Fredman B, Zohar E, Rislick U, Sheffer O, Jedeikin R. Intrathecal anaesthesia for the elderly patient: the influence of the induction position on perioperative haemodynamic stability and patient comfort. Anaesth Intensive Care. 2001;29(4): 377-82, doi: http://dx.doi.org/10.1177/0310057X0102900408

14. Han G, Zhao GY, Li L, Zhao P. Comparison of hemodynamics after combined spinal-epidural anesthesia between decubitus and sitting positions in aged patients undergoing total hip replacement. Pharmacology. 2014;93(3-4):193-6, doi: http:// dx.doi.org/10.1159/000362214

15. Obasuyi BI, Fynaface-Ogan, Mato CN. A comparison of the haemodynamic effects of lateral and sitting position during induction of spinal anaesthesia for caesarean section. Int J Obstet Anesth. 2013;22(2):124-8, http://dx.doi.org/10.1016/j. ijoa.2012.12.005

16. Inglis A, Daniel M, McGrady E. Maternal position during induction of spinal anaesthesia for caesarean section. A comparison of right lateral and sitting positions, Anaesthesia. 1995; 50(4):363-5, http://dx.doi.org/10.1111/j.1365-2044.1995. tb04620.x

\title{
Sažetak \\ UČINAK POLOŽAJA BOLESNIKA NA RANE KOMPLIKACIJE INDUKCIJE SPINALNE ANESTEZIJE U ARTROSKOPSKOJ OPERACIJI KOLJENA
}

\author{
E. Kongur, S. Saylan i A. Eroğlu
}

Spinalna anestezija uobičajena je metoda koja se primjenjuje u različitim položajima bolesnika stvarajući učinkovitu i brzu indukciju anestezije u kirurškim intervencijama. Rane i kasne komplikacije spinalne anestezije mogu se razlikovati ovisno o vrsti igle, koncentraciji i dozi lijeka, težini i visini bolesnika, tehnici uboda i položaju bolesnika. Cilj ovoga istraživanja bio je prospektivno usporediti rane komplikacije spinalne anestezije kod bolesnika koji sjede i u bočnom dekubitusu s vremenom početka blokade motora i osjetnom blokadom do razine T10. U ovom istraživanju spinalna anestezija primijenjena je na 100 bolesnika s ASA I-II u dobi od 18-65 godina (skupina $S=48$, skupina L=52) koji su bili podvrgnuti artroskopskoj operaciji koljena. Zabilježeni su hemodinamski podaci, rane komplikacije, vrijeme nastanka senzorne i motorne blokade. Sistolički tlak, dijastolički tlak i srednji arterijski tlak bili su značajno niži u položaju bočnog dekubitusa nakon indukcije spinalne anestezije u usporedbi sa sjedećim položajem. Vrijednosti arterijskog krvnog tlaka značajno su se smanjile u položaju bočnog dekubitusa u usporedbi sa sjedećim položajem. Vrijeme nastupa motoričke blokade i vrijeme početka osjetne blokade bilo je kraće u položaju bočnog dekubitusa u usporedbi sa sjedećim položajem. Rezultati pokazuju da se sjedeći položaj može preporučiti tijekom indukcije spinalne anestezije, jer se krvni tlak manje snižava u tom položaju.

Ključne riječi: Spinalna anestezija; Indukcijski položaj bolesnika; Bočni dekubitus; Sjedeci položaj; Rane komplikacije 